\title{
CARING MASCULINITY OR HYBRID MASCULINITY? AN ANALYSIS OF RESEARCH RESULTS ON MALE NURSES IN POLAND
}

\author{
URSZULA KLUCZYŃSKA ${ }^{1}$ \\ ${ }^{1}$ Collegium Da Vinci, Faculty of Social Sciences, ul. gen. Tadeusza Kutrzeby 10, 61-719 Poznań, Poland. \\ ORCID: 0000-0002-5139-6813,Email: urszula.kluczynska@cdv.pl
}

\begin{abstract}
In studies on men and masculinities, there is an increasing number of theories, which result from development, discussions and criticism in the area. However, in the context of this paper, two ways of describing masculinities are taken into account, i.e. caring masculinities and hybrid masculinities. The article analyses research results on male nurses in Poland, which were performed by means of in-depth interviews, according to theoretical assumptions on caring and hybrid masculinities. The interviews revealed varying ways of perceiving masculinities in the context of care. Out of the ways identified by the Author, the study focuses on the analysis of how to define masculinity as a belief that masculinity is accomplished by ensuring hegemonic masculinity. It also shows how this way of defining masculinity is related to the assumptions of hybrid masculinity. As a result, the analyses show that caring masculinities are not only diverse but also that the very term is disputable with regard to masculinities involved in various types of care.
\end{abstract}

KEYWORDS: masculinities, caring masculinities, hybrid masculinities, hegemonic masculinities, care, CSMM

\section{INTRODUCTION}

Critical Studies on Men and Masculinities (CSMM) are a developing area, so new terms and categories defining masculinities are formulated. At the same time, new terminology is criticised for being structuralist and following post-modernism 
terms in modernism descriptions (Berggren 2014). Apart from the dominant hegemonic masculinity theory of R.W Connell (1995), and other related masculinities, such as complicit, marginalised and subordinated, the CSMM mention toxic (Kimmel 1995, 2013), inclusive (Eric Anderson 2009), hybrid (Demetriou 2001; Bridges \& Pascoe 2014) as well as caring masculinities (Elliott 2015). Although descriptions of masculinities are based on assumptions and contexts, e.g. decreasing homophobia levels in relation to inclusive masculinity, they only deal with certain models of masculinities, thus following a trend that distinguishes masculinity types (Waling 2018). From my perspective, these numerous categories of masculinities overlap, and it is difficult to demonstrate relationships and interconnections between them. An example of an analysis that describes some of these relationships and interconnections is Karla Elliott's (2020) proposal of open and closed masculinities.

The main aim of the article is an attempt to reconceptualization the concept of caring masculinities. The research I carried out among male nurses showed that in some circumstances, men's participation in care might support gender hierarchy. That is why I analyse relationships between caring masculinities, as described in my research, and hybrid masculinities. The focus is on one of the ways of defining masculinities in the context of care, which is related to the ways of understanding hybrid masculinities. Empirical studies (Kluczyńska 2017b), being the basis of my considerations, are not described here in detail. The article aims to reflect upon terminology and find relationships within the analysed categories.

\section{CARING MASCULINITIES - DEFINING AND CONTEXT}

While analysing the concept of caring masculinities, I also describe feminist considerations on care as an activity thought to be connected with femininity (Kluczyńska 2017a). This element is important for defining the core of caring masculinities. Besides, I quote research on caring masculinities, emphasise its value as being pro-equality, and refer to my research on caring masculinities accomplished by ensuring hegemonic masculinity.

\section{Feminist analysis of care}

Any feminist analyses of care and concepts of care ethics start with the situation of women. These theories constitute a good perspective for caring masculinities because care is a universal human responsibility, even though it is entangled in numerous relationships, including gender-related ones. Because defining caring masculinities is based on care as such, though generally perceived as a female activity, I briefly present feminist analyses of care in order to highlight basic relationships.

Having reviewed historical ways of interpreting and analysing care in the context of gender, we should look at the first wave of feminism because it focused on women's unpaid care work. That work was not associated with gender as it was treated as a natural female domain (Philips 2009). The second wave of feminism emphasised dissimilarities between care provided by men and women, and praised the specificity of 
caring activities provided by women (Philips 2009). Clare Ungerson (1987) differentiated between 'care for someone' and 'care about someone', and assigned the former to women and the latter to men. Thus, care was perceived from two dimensions: 1) 'care for' as selfless emotional work assigned to women; and 2) 'care about' as financial and managerial work seen through the prism of privileges assigned to men (Philips 2009). Assigning care to women was based on a conviction that they had better abilities to recognise needs due to their experience of motherhood. The third wave of feminism was connected with sexual integration, appreciation of women, and integration of care economics (deprived of the negative, subordinated role) (Mattahaei 2001). What is essential here is the 'ethics of care' that goes beyond biological determinism and replaces previous attitudes, which described women through work ethics, whereas men through fairness ethics (Gillan 1982). Also, care was no longer categorised as public and private, male and female. As a result, care and its crucial role in life have been emphasised (Philips 2009; Engster 2009; Baier 1985; Fineman 2004; Kittay 1999).

In the above sense, care is the first and foremost human activity that is precious and interdependent by its very nature. It can be a source of satisfaction even if it is strongly reliant. The point is not only to appreciate care, but show its human dimension. Care is also seen from the gender perspective, where the main role is played by the woman who is usually obliged to provide care. This perception of care as a human activity should also be taken into account while discussing masculinities. We should consider how care can affect defining masculinities or how men can define care.

\section{Care vs hierarchical model of masculinities}

Hegemonic masculinity (Connell 1995) is defined as masculinity that does not undertake care (Hanlon 2012). It is a privilege of dominant masculinity which - by subordinating femininities - assigns this issue to women or expects other masculinities to perform the task, i.e. subordinated masculinities. Men who accomplish complicit masculinity (Connell 1995) undertake care because by starting a family and fatherhood, they compromise and accomplish a more active role of a father or a carer.

Niall Hanlon (2012) describes why care is absent in the traditional pattern of masculinity and basically sees it as an element of femininity as opposed to masculinity. In hierarchically arranged gender relationships, care is associated with feminisation and a symbolical step towards or into a group of subordinated masculinities. Besides, care is described as an activity men are not good at and cannot perform it well. Such arguments, based on 'natural abilities', are supported and copied by biologist and determinist attitudes which sanction 'naturalness' of women and undermine the universal character of care. In relation to women and men alike, care is a relationship that should include the needs of both parties that are interdependent. All participants of the process have to learn specific actions, recognise one another's needs, and modify activities. Thus, it cannot be stated that care is something men are not able to do, and it is something they have to learn. Hanlon (2012) says that providing care means that traditional masculinity abandons its authority, a situation that can be unacceptable to some men. Accomplishing caring masculinities, thus giving up privileges and power 
ascribed to traditional masculinity, may bring about social ostracism resulting from forgoing a conformist male role (Elliott 2015).

When care is undertaken through the prism of the hegemonic masculinity theory, inevitable consequences arise. First of all, some men are excluded from care or care is seen through the prism of power. When a man participates in care, he may move down in the masculine hierarchy, providing such a hierarchisation of masculinity exists. According to research, men who undertake care work (nurses) often come from ethnic minorities, and a medical job becomes a kind of social promotion. In R. W Connell's terms (1995), men who belong to subordinated masculinities may undertake care work without a threat to hegemonic masculinity. It can result from the way hegemonic masculinity is defined in a given culture and the very fact that they belong to subordinated masculinities. Performing care work does not undermine their position in the masculinities hierarchy. In some situations, they can even get socially or financially promoted despite doing a 'feminine' job or exactly because of doing it. Studies show that for men from small villages or poor families, doing a care job is a sign of social promotion, and its 'feminine' character is unimportant (Kluczyńska 2017a). Other groups that could be defined as subordinated masculinities according to Connell's theory, e.g. gay, may have a different attitude towards a care job and performing care work. This results from the fact that they already belong to a subordinated masculinity group, and they have 'little to lose', because they are already associated with women, and a 'feminine' job changes little in that respect.

\section{Caring masculinities - beyond hierarchy}

Defining care is crucial for the perception of caring masculinities beyond the hierarchical division. Care is a universal activity that is a value both for its recipients and providers. It is more and more often appreciated by society, as demonstrated by an increasing prestige of the nursing profession (CBOS 2019). A feminist analysis of care clearly shows that care work is the one that has to be done, and it is of utmost importance for the sense and preservation of humanity (Elliott 2015). Appreciating care can change the position of caring masculinities against hegemonic masculinity. However, if masculinities are to be analysed horizontally, a number of aspects and negative connotations which contribute to a drop in the hierarchy, according to Connell, would have to be changed or removed, such as skin colour, sexual orientation, background, and material resources. Likewise, the hierarchical perspective of masculinities could be turned down for the sake of the horizontal one, which would perceive caring masculinities as a dismissal of domination.

Caring masculinities can be seen in everyday life of men as it regards care activities in families and the community, as well as 'female' care jobs, but it also concerns activities connected with self-care, i.e. taking care of one's health and emotions by reducing behaviours hazardous for health, but also cherishing friendships and close relationships. Caring masculinities are an option for men who are the family's breadwinner (Scambor et al. 2015). Therefore, it is an alternative to hegemonic masculinity, whose cost can be eliminated and substituted with benefits offered by accomplishing 
caring masculinities .

In Karla Elliott's (2015) view, what is vital for the caring masculinity model is the very fact of rejecting domination and an integration of values derived from the realm of care, i.e. positive emotions, interrelationships, and maintaining a relationship. Not only does caring masculinity model reject the pursuit of domination, but it also highly values positive emotions (Elliott 2015; Hanlon 2012). This is an apprehension of values and satisfaction derived from care both on the theoretical and practical levels. Studies carried out by Niall Hanlon (2012) showed that providing care let men feel responsible, competent, happy, proud, and cheerful. Similar results were obtained in research on male nurses in Poland (Kluczyńska 2017a). Hence, values associated with care become a source of accomplishment and fulfilment.

Caring masculinities can be a rejection of the load of rules that classify masculinities in the hierarchical system. In this way it is a step towards gender equality (Hanlon 2012; Scambor et al. 2014; Elliott 2015; Flood \& Howson 2015) that does not struggle for power but for diversity. Caring masculinity can be seen as pro-equality masculinity. Basically, a pursuit of gender equality is ascribed to femininity, because it is assumed that women may achieve most benefits when gender equality is implemented. Nevertheless, this issue is connected with the cost paid by women, but also by men as a result of dominant or subordinated masculinities. Thus, researchers suggest that it is essential to include men in endeavours aiming at gender equality (Scambor et al. 2014), because contrary to a common belief they may benefit from such a change.

Indeed, involving men in childcare and household duties, stereotypically seen as feminine tasks, is pro-equality. When men are involved, it is not only women whose situation improves, but it is also to the advantage of men, and their emotional and psychosocial wellbeing. Studies show that an engaged man profits from better bonds with the child, as well as an overall satisfaction from life and the relationship. So, it affects positively both men themselves and other family members. The very participation in care contributes to the quality of life, health, lower number of risky behaviours, lower violence, and a better relationship (Scambor et al. 2012). Care - even if it is a must - has the potential to bring about changes in the way of thinking about care and the position of care as an element that constitutes a man's identity. In short, care work changes gender, and it changes men (Hanlon 2012).

\section{CARING MASCULINITIES IN RESEARCH ON MALE NURSES IN POLAND}

On average, one person in ten working in nursing is a man, but in Poland men constitute only $2.5 \%$ of the nursing staff (Naczelna Izba Pielęgniarek i Położnych 2018). The modern model of nursing, developed in the 19th century by Florence Nightingale, contributed to this profession being associated with femininity, which prevented men from entering it. On the other hand, nursing gave women an opportunity to leave their private sphere and pursue a career (Mackintosh 1997; O’Lynn 2007). Nowadays, care has become a profession and it is treated as a job that requires certified skills and competences. In this way, 'formal care' as professional work, here nursing, received a higher status than informal care, not to mention an income that accompanies it. 
Research on attitudes to various jobs in Poland shows a rise in the society's regard for nursing jobs (CBOS 2019). In fact, nurses enjoy a high prestige in Poland, but the profession remains to be underpaid, although the pay depends on terms of employment.

According to studies carried out among male nurses in Poland, their choice of the profession is of a polimotivational character (Kapała \& Rucki 2008; Domagała et al. 2013; Dziubak \& Motyka 2013; Kluczyńska 2017b), including vocation, medical interests, pragmatic reasons, and chance. What is more, Bradley (1993) shows that the fact that men enter feminised professions is connected with advancement in technology and economic opportunities.

Men in a feminised job are able to make use of promotion mechanisms (Kluczyńska 2017a), which allow them to be promoted to senior positions, i.e. a ward nurse or a chief nurse, but - above all - they can work is specialist laboratories, and under a contract, which is known as a horizontal promotion. Working on contract is a kind of self-employment, under which it is possible to negotiate higher pay, but there is lower job stability and no possibility for a paid holiday. For these reasons female nurses that also look after their family members in the private sphere are less likely to work on contract.

Masculinity understood as dominance and aggression enables men to reach higher posts and higher income as they perceive negotiating their pay as male strength and dominance. In this way such masculinity sustains the gender order that is based on inequalities (Kubisa 2012). Still, it has to be remembered that not all men strive for dominance and promotion.

Studies (Kluczyńska 2017a, 2017b) show that undertaking a care job and providing care may, but does not have to, be connected with the rejection of dominance. Although motivation for choosing nursing in Poland may vary and may be of an internal or external character, the fact that a care job is taken does not mean a rejection of aspirations to accomplish hegemonic masculinity. The paragraphs below describe all types of masculinities revealed by the research among male nurses. This complex description shows the rich ways in which masculinities can be defined as well as the relevant background. However, in the context of care the most important definition of masculinity is based on a belief that masculinity is accomplished by ensuring hegemonic masculinity.

\section{Method}

The analysis is based on individual, semi-structured, in-depth interviews. The study included 24 licensed male nurses working in the profession for at least two years. The number of respondents was associated with data saturation. A purposive sampling method was utilized. I reached the respondents by informal means and utilizing the snowball effect afterwards. The interviewees included male nurses working on various wards, in units, and clinics. The interviews were recorded, transcribed, and analyzed according to the premises of the grounded theory method (Charmaz 2006, 2011). Data were collected between January 2014 and December 2015 in Poland (Kluczyńska 
2017a, 2017b).

\section{Results. Ways of defining masculinity in the context of care}

The collected data let me describe different ways of defining masculinity in the context of care. Two of them define masculinity by negation: masculinity as the opposition to femininity, and caring as non-masculinity. The first two ways of defining masculinity in the context of care are based on negation, the first of which is described as an opposition to femininity or rather an opposition to how 'what is feminine' and 'what is masculine' are imagined. Being a woman or a man is defined by differences and based on biological determinism, gender stereotypes, and gender order. Then, masculinity is the negation or the opposite of caring. The next two show how masculinity is accomplished by ensuring hegemonic masculinity, and accepting caring masculinity. The following two ways of defining masculinity in the context of care stem from the common ground of feeling confident about one's masculinity, where there is no place for fear or negation. Just the opposite, there is a conviction that 'everything is in the right place'. So, care can be integrated into the concept of masculinity in different ways. Finally, masculinity is defined by suspending gender in the context of care.

1. Defining by negation - masculinity as the opposition to femininity

Here, masculinity is defined on the principle of a binary opposition. Masculinity is non-femininity.

I'm a man because I not a woman. (Teodor)

Those men take gender order and men's domination for granted, which is supported by biological differences, so to say for them 'biological' means 'natural' and 'certain'. No need to say that these differences reinforce gender inequality.

I pee standing and I stick to it. (Andrzej)

Because this point of view assumes that masculinity is non-femininity, 'male care' must be distinct from 'female care'. 'Female care' applies to some dimension of care: care about, emotional support, meticulousness, whereas 'male care' is thought to be rational, task-oriented and medical.

From this perspective, care is linked with femininity, and perceived as the core of femininity, and a 'natural' inclination to fulfil the role of the mother. Care provided by women focuses on nurturing, demanding accuracy and carefulness in tasks which man tend to skip. These men think that 'female care' is not crucial and rather 'cosmetic'. On the other hand, 'male care' is understood as different and more important than 'female care'.

Men are more task-oriented. They've got their tasks and they carry them out one by one, whereas for women it's connected with maternity. It's their attitude and they give more. We - I mean guys - do what is necessary. (Andrzej)

Men lack what women have patience. Women do everything meticulously, while men 
don't notice that something is dirty. Men only do what is necessary, but it doesn't mean that something bad will happen to the patient. (Jerzy)

\section{Defining by negation - caring as non-masculinity}

The second way of defining masculinity in the context of care is founded on the perception of caring masculinity as non-masculinity. Here, masculinity is the negation of femininity, and it is based on a binary opposition which excludes femininity. However, it does not take into account complexity, and rules of other varieties of masculinity. Thus, masculinity defined as a negation of caring is associated with differences and inequality, which are thus further confirmed and ensured.

This point of view is something more than a negation of femininity, because it is connected with being afraid of stereotypes of men in nursing. According to these stereotypes, being a man in nursing means being closer to femininity and being subordinated to other men (e.g. being gay). From this perspective masculinity and care are based on negation, fears and homophobia. These feelings may discourage men from providing care and choosing nursing professions.

Here, caring is understood as being close and supportive. Caring is non-masculine: it is feminine or it is a part of subordinate masculinity. Care which is perceived as masculine is limited to providing security, performing instrumental or medical tasks, all of which are deemed more prestigious.

According to the respondents, there is an alternative for men in nursing: a specialisation with limited care or a medical job other than nursing, for example a radiation therapist or 'in the ambulance as it is a job more for a man.' (Szymon)

Men whose attitude to care is the opposite of masculinity tend to be fearful and lack confidence. However, some of them stay in the profession for some reasons, others quit it. The fact that their dominant version of masculinity is endangered prevents them from feeling fulfilled in the job or makes them resign. What's more, the fear and insecurity with regard to their masculinity results in frustration.

Nursing. A guy doesn't quite fit in. For me, if I were financially satisfied (...), but in fact I've never felt entirely fulfilled, and it's not quite what I should be doing, it's not quite what a man should be doing (...), even if I were financially satisfied, I would still feel it mentally. (Bartosz)

3. Feeling confident about one's masculinity - ensuring hegemonic masculinity

Here, the key to feeling confident about one's masculinity in the context of care is a conviction that some model of a dominant form of masculinity is fulfilled. For these male nurses hegemonic masculinity is important, and they claim that they have succeeded in this respect as they feel that they have power. For them, working in a caring profession does not endanger their dominant version of masculinity.

The fact that I work in nursing doesn't affect whether I feel masculine or not. I don't have a problem with that and don't have to prove that it's masculine and I'm mas- 
culine. I feel masculine and I am masculine. Obviously, the profession is feminine, because it's usually women who do it. People can tell me it is a feminine job, but I'm not bothered by that. (Szymon)

Men from this group declare they have hardly considered what it means to be a man, or wondered what masculinity means to them. They have not reflected on it in the context of working in a caring profession. These men define care as a part of professional work, and there is no dissonance in the model of hegemonic masculinity. The fact that they work in nursing does not mean that they continue or realise caring or nurturing activities in their private life. They define care as medical and specialist tasks, not as nurturing. They usually work in specialist wards, and they earn more, because they work on contracts. They feel they have an impact on the situation, and they are not afraid of change or risk taking. What is more, they are the men who use the 'glass elevator' mechanism and make use of the privilege of being a man in a feminized profession. They also assume that their participation in a feminised occupation can positively affect its prestige, for example by raising wages.

If there were more men, nurses would have more clout. I saw it during strikes. When nurses went on strike and we were going [to Warsaw], lots of women, they were staying outdoors in tents, they had no clout. When miners went there, they demolished half of the city, and on the following day everything [they wanted] was signed. (Patryk)

I think men are needed even for the ordinary talks. We are all employed under civil law contracts, but if not for those men, for example my colleague or myself, ladies from wards would still be getting little money under those contracts. (...) Because of stress and pressure, some of the ladies would have given in in the negotiations. It's because of fear that they would lose what they've got. Obviously, it is to do with their nature, family, kids and so on. A guy has got a different attitude: 'Well, if not this job, there will be another one'. Of course, it is not quite like that, but under the influence of adrenaline and all that, men do have a different attitude. (Tomek)

From this point of view nursing is for men, but 'the real men', who aspire to hegemonic masculinity, able-bodied, powerful, who like sport, and make use of privileges as a man.

4. Feeling confident about one’s masculinity - accepting caring masculinity

When talking about feeling confident in the context of masculinity, male nurses do not often refer to hegemonic masculinity. They draw confidence from alternative masculinity, which is not defined by negation, homophobia, but by a multiplicity and - what is important - a non-hierarchical system. These men accept their weakness and they are ready to look for support. Here, masculinity is closely linked with care, because for them care is an inherent part of masculinity. Care is seen in a wide context, also as nurturing and closeness. Men from this group stress that they have a chance to be themselves. They accept caring as the core of masculinity. 
I'm tender and that's how I know I feel good in this job, because I don't have to pretend to be some macho in a metalwork workshop or at a garage. I don't have to pretend that I'm someone I'm really not. I'm fulfilled in both roles professionally and personally. (Błażej)

\section{Suspending gender in the context of care}

Men from the last group do not mention gender as an important factor when choosing nursing. They usually omit this aspect. Being a man or a woman is not important for them in the context of care. They chose nursing because of their interests, they suspended gender in the context of care. My respondents very often skipped the aspect of gender as they were talking about nursing, nursing situation in Poland, different aspects of care, and even used feminine name for their profession. (In Poland the word 'pielgniarka' means a she-nurse, it is a feminine form; it is the official name of the profession, although there is a masculine form 'pielęgniarz"). For them it was not a problem. Above all, for them care is an activity, a profession that confirms humanity.

Is it masculine to be a nurse? Can't say as I've never seen it in that category. I just work in this profession and I'm a man, so it must be so. (...) You can't measure everyone against the same pattern, and it's also true with gender and profession. (Hubert)

I don't consider the job in this category whether it is masculine or feminine. Simply, I'm in this profession. (Dawid)

Defining masculinities is closely connected with power and subordination, i.e. the gender order. Defining or aspiring to masculinity through hegemonic masculinity or treating it as a reference point is linked with a belief that men's domination over women and other men is right. Defining masculinities is linked with the way care is realised, but also with appreciating care in developing one's masculinity. Caring can be seen as an aspect undermining masculinity or as a stereotypical 'female trait' which also threatens masculinity. In this situation care is perceived through the prism of power, and men tend to avoid less prestigious aspects of care, especially nurturing. This way of thinking about masculinity versus care supports men's domination and gender order. Another way of describing masculinities deals with confidence. It is about how confident one feels about realising a dominant version of masculinity or caring masculinity. In the first situation - which strengthens the gender order - authority as well as a profitable job are crucial. In the second one - which undermines the gender order - care is defined widely as care about, emotional support or an activity which brings satisfaction. Finally, masculinity in the context of care can suspend gender, and treat caring as an activity which confirms humanity.

The results of my analyses show that working in nursing may be, but does not have to be, connected with abandoning hegemony. A caring job does not always mean rejecting aspirations related to hegemonic masculinity. In this situation nursing is often defined through traditional masculinity, and men tend to step back from low-ranked 
tasks. They also tackle the dissonance of working in a feminised occupation by re-defining 'femininity' of the job, and attributing higher quality of the performed tasks to men as well as higher incomes. Simultaneously, many men who take up the profession feel they fit in, and draw satisfaction from a caring job and fulfilling caring masculinity (Kluczyńska 2017a, 2017b).

\section{HYBRID MASCULINITY. CAN THE HIERARCHY BE SKIPPED?}

Hybrid masculinity, a concept mentioned in analyses on masculinities, is described in detail by Tristan Bridges and C. J. Pascoe $(2014,2018)$. In order to discuss research results on male nurses, it is worth specifying what hybrid masculinities are.

The concept of hegemonic masculinity was criticised by Demetrakis Z. Demetriou (2001), who claimed that hegemonic masculinity was not an entirely white or heterosexual configuration of practice, but a hybrid masculine bloc that united various masculinities so as to guarantee patriarchal reproduction. Demetriou analyses hegemonic masculinity, which is always presented in relation to women and subordinated masculinities (Connell 1987). When conditions that enable patriarchal reproduction change, hegemonic masculinity changes, too (Connell 1995). Demetriou (2001) coined a term 'dialectical pragmatism' which describes abilities to include appropriate elements of subordinated masculinities and marginalised into hegemonic masculinity. He also claims that the strength of hegemonic masculinity relies on this very ability to adapt, and it should be understood as a bloc capable of encompassing what is useful and constructive for the domination project in a given historical moment (Demetriou 2001). Demetriou undertakes to deconstruct the binary between non-hegemonic masculinities and hegemonic masculinity by offering a new term 'a hybrid masculine bloc', which combines various practices with the aim to create the best possible strategy for patriarchal reproduction. Thus, hybridisation is a reproduction strategy of patriarchy, and hegemony reproduces through hybridisation.

Indeed, studies prove the specific character of hybrid masculinities. On the example of Promise Keepers movement, Brian Donovan (1998) shows how hybrid masculinity is created as a combination of men's sensitivity and strength, and thus a new form of authority is created which enhances the authority of men. According to Schindler (1997), Promise Keepers' members are trying to regain traditional gender roles by means of inclusive discourse, sympathy and brotherhood. Then, Demetriou (2001) demonstrates how the inclusion of elements from gay culture contributes to the creation of hybrid masculinity, which enables dominance over women.

Hybridisation contributes to an illusory belief that gender practices become less oppressive and more egalitarian (Demetriou 2001). For example, if men pay attention to grooming, the dominant masculinity form becomes milder, and on the symbolic level it opposes modern femininity in a lesser degree. However, Donovan (1998) says that it is an illusion, because milder forms of masculinity do not affect women emancipation, but rather conceal usurpation of women rights. Therefore, hybridisation is a form of camouflage or masquerade that lets uphold patriarchal reproduction (Demetriou 2001). What is more, Michael Messner (2007) talks about an 'emergent hybrid mascu- 
linity'. He describes Arnold Schwarzeneger who became governor of California, owing to his image based on a combination of strength and gentleness in a way that tends to conceal rather than undermine the system of power and inequality. Actually, Messner describes hybrid masculinity in his earlier analyses, in which he features a New Man who - emphasises the author - 'is more style than substance, he is self-serving and no more egalitarian than the traditional man, and thus does not represent genuine feminist change' (Messner 1993:724). As Tristan Bridges and C.J. Pascoe (2014) say, an inclusive masculinity model of Eric Anderson (2009) is an example of hybrid masculinity. It assumes an inclusion of cultural aspects which are perceived as 'Others'. Nevertheless, research on the transformation of masculinities is basically performed on groups of young men who identify themselves as straight. This observation shows that only the privileged can afford such flexibility. Still, in Tristan Bridges and C.J. Pascoe's view (2014) not only this group realises hybrid masculinities, as marginalised and subordinated masculinities can also do so.

According to Tristan Bridges and C.J. Pascoe, hybrid masculinity 'refers to men's selective incorporation of performance and identity elements associated with marginalised and subordinated masculinities and femininities' (Bridges \& Pascoe 2014: 246). Hybrid masculinity is a change of masculinity, which is connected with issues of hierarchy and subordination, and followed by a few consequences. 'First, hybrid masculine practices often work in ways that create some discursive distance between young, white, straight men and hegemonic masculinity, enabling some frame themselves outside the existing system of privilege and inequality. Second, hybrid masculinities are often premised on the notion that masculinities available to young, white, straight men are somehow less meaningful than masculinities of various marginalised and subordinated Others, whose identities were at least partially produced by collective struggles for rights and recognition. Third, hybrid masculinities work to fortify symbolic and social boundaries between (racial, gender, sexual) groups - further entrenching, and often concealing, inequality in new ways." (Bridges \& Pascoe 2014: 250)

Tristan Bridges and C.J. Pascoe, (2014) elaborate on three consequences associated with constructing hybrid masculinities: discursive distancing, strategic borrowing, and fortifying boundaries. They describe a process how significance and practices of hegemonic masculinity change with time in a way that maintains gender regimes, domination of men over women, and domination of some groups of men over other men (Bridges \& Pascoe 2018).

In the first place, discursive distancing creates a belief that hybrid masculinity distances itself from hegemonic masculinity, whereas it actually supports it. Research provides examples of hybrid masculinities' practises. Bridges and Pascoe (2018: 261) demonstrate bromance, i.e. a close relationship between men, which is emotional, intimate, non-sexual, but including intimate touch. Such a relationship seems to reduce distance between hegemonic masculinity and intimacy, simultaneously undermining the essence of homophobia in contemporary ways of forming masculinity. The very word 'bromance' comprises romance, so it is an intimate bond between pals or bros. Thus, symbolically 'bros' emphasise a straight relationship, which distances it- 
self from an erotic relation between a man and a man, even though intimate touch is possible in this relationship (Bridges and Pascoe 2018). Furthermore, Bridges (2010) and Master (2010) provide examples of male practices, whose aim is to show their support to women and distance from sexism and domination over women, i.e. elements of hegemonic masculinity. Discursive distancing also shows ways how men can enter practices which can be described as 'feminine' (Bridges \& Pascoe 2014). Kristen Barber (2008), who analysed beauty parlours, shows how men participate in 'feminine' activities, such as pedicure and manicure, which ensure their status against other men.

The second consequence of constructing hybrid masculinity is strategic borrowing (Bridges and Pascoe 2014). Hybrid masculinities are realised by men from privileged groups who borrow symbols associated with various 'Others' that let them define themselves as part of marginalised or subordinated masculinities (Bridges \& Pascoe 2018: 263-264). An example can be hipster culture which borrows elements from the working class. Another example is an inclusion of gay culture among straight men, i.e. metrosexualism (Bridges \& Pascoe 2018: 264). When a young white straight man borrows practices and identity elements from subordinated groups to strengthen his masculine capital, the borrowed elements confirm the deviant character of these subordinated groups, thus enhancing the system of power and dominance (Bridges \& Pascoe 2014).

Finally, the third consequence of hybrid masculinity is fortifying boundaries (Bridges \& Pascoe 2014, 2018). Bridges and Pascoe claim that seizing masculinity elements or practices subordinated by young white straight men contributes to blurring boundaries between these groups as 'hybrid masculinities further entrench and conceal system of inequality in historically new ways, often along lines of race, gender, sexuality and class' (Bridges \& Pascoe 2014: 254). While carrying a study on white straight men making sex with other men who identify themselves as straight, Jane Wards (2008, 2015 ) shows the process of fortifying boundaries. These analyses demonstrate that white men seeing themselves as straight can have sex with other men free of identity consequences.

\section{CARING MASCULINITY VS HYBRID MASCULINITY IN THE CONTEXT OF STUDIES ON MALE NURSES IN POLAND}

It is worth reminding that hegemonic masculinity, being a certain 'cultural ideal' accessible only to some, is a point of reference (Connell 1995) and definitely it is a non-caring masculinity. Quoting R.W Connell's theory, men who provide care and 'compromise' because of various reasons realise complicit masculinity. Among male nurses there are also men who - according to Connell's theory - can be assigned to subordinated masculinities, especially homosexual men, men from ethnic minorities, working class or rural areas (Kluczyńska 2017a). However, most male nurses can be described as those who realise complicit masculinity. Basically, care is undertaken by women and subordinated masculinities or - if the consent and decision is conscious - complicit masculinity, which benefits from the privileges of masculinity, i.e. patriarchal dividend. On the other hand, caring masculinity model 'rejects domination and 
its associated traits embrace values of care, such as positive emotion, interdependence, and relationality' (Elliott 2016: 240).

The above considerations and clarifications are indispensable to put the analysed group of male nurses in the perspective of masculinity categories, especially hybrid masculinities. Analyses on hybrid masculinities are embedded in the reflexion and criticism of Connell's theory. In this article the focus is only on one out of five ways of defining masculinity in the context of care, i.e. defining masculinity as a belief that masculinity is accomplished by ensuring hegemonic masculinity. Among this group there are able-bodied, white, straight men whose income is high. What they have in common is the financial success in a profession which is seen as low-income, they also work in specialised units, they are promoted (using the 'glass elevator' mechanism), they feel they make a difference, and they are not afraid to take risk. In fact, work in specialised units usually means that they are not involved in care activities of the lowest prestige, even though initially each of them did care work as part of nursing chores. In fact, they perceive basic care activities as a part of the nurse's work, but this aspect does not concern them anymore. In their view, care is defined as an element of work, not an element of private sphere. After all, they are nurses and they do care work (Kluczyńska 2017a).

Hybrid masculinity model is connected with discursive distancing. Although it is based on distancing from hegemonic masculinity, it actually supports it. So, by working in a nursing profession, whose core is care, men distance themselves from hegemonic masculinity, which is defined as a masculinity which does not undertake care and delegates care activities to femininity or masculinities whose position in the masculinity hierarchy is lower. Definitely, men who work as nurses accomplish caring masculinity, not hegemonic masculinity, by virtue of the profession's character. Doing a 'female' job, i.e. care, distances men from hegemonic masculinity. Still, this distance may be illusory, because what matters is how care is defined by male nurses themselves. Therefore, it is important to recognise how they redefine practices borrowed from subordinated groups. Strategic borrowing means that symbols associated with subordinated masculinities and femininities are borrowed from them. Indeed, this is what happens in the analysed situation. White straight male nurses borrow care, enter a profession, redefine their position, make use of their features (being a white straight man), and emphasise differences between themselves and subordinated groups, such as female nurses, gay nurses, what in fact strengthens the system of domination and hierarchy. In this way, boundaries are reinforced, even though apparently they are redrawn. Some men accomplish caring masculinity in nursing, however, others redefine care and make use of privileges of men, i.e the patriarchal dividend. Re-defining care and types of tasks, as well as enjoying privileges in a feminised profession lets one stand out, and reinforce the boundary between caring femininity and caring and subordinated masculinities, especially gay. Therefore, it is 'others', i.e. subordinated, who perform care activities of the lowest status. Needless to say, in this way boundaries are reinforced, even if it happens in a different way, and the division between 'us' and 'others' remains. Reinforcing boundaries is also important because in a feminised caring profession, i.e. nursing, care as the pivotal element of the profession is 
so closely linked with femininity that it needs an effort and persistence to dissociate oneself from performing 'feminine' care and the existing stereotypes which associate male nurses with subordinated masculinities. Fig. 1 shows aspects which male nurses aspiring to hegemonic masculinity use to constitute hybrid masculinity.

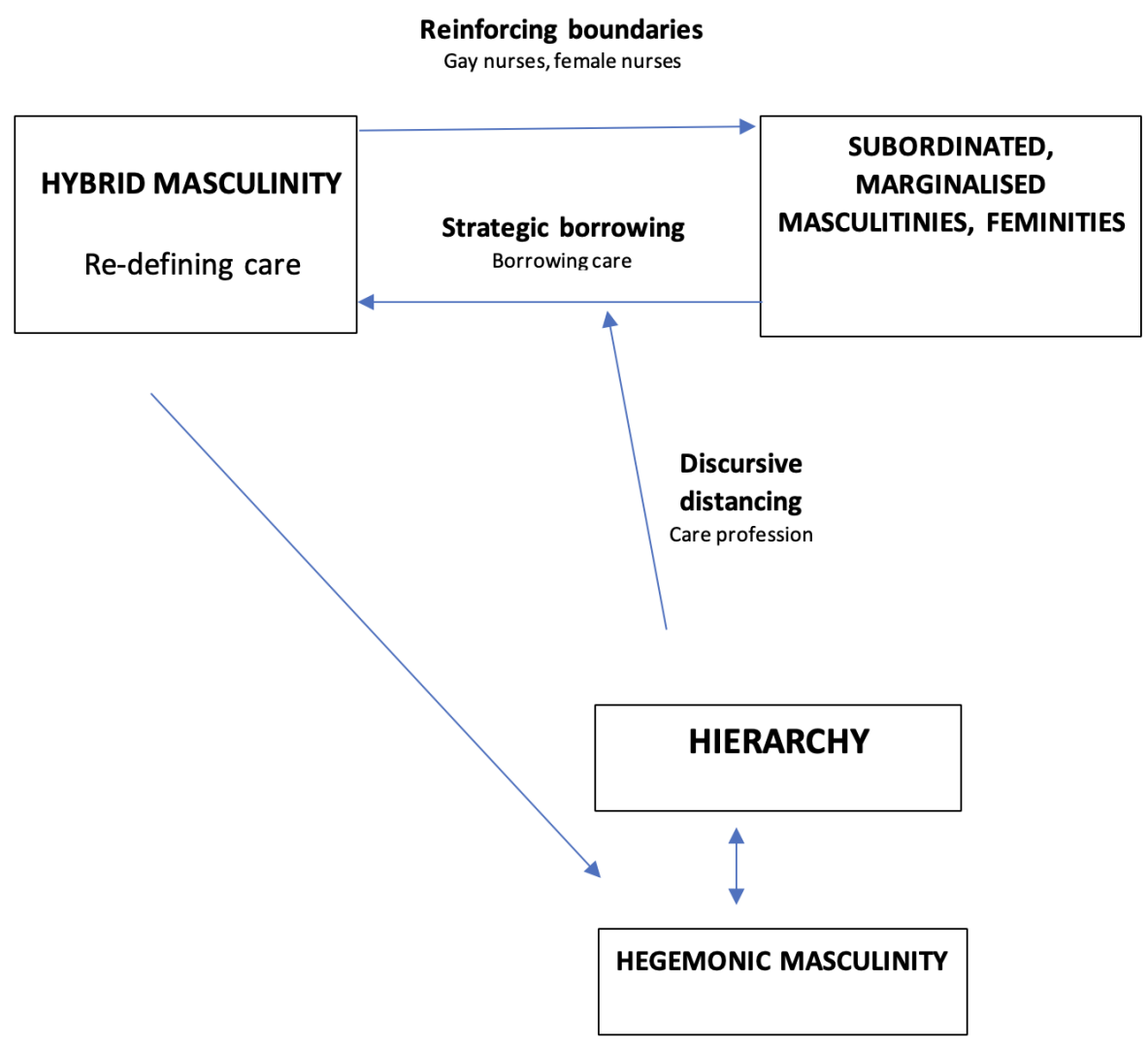

Figure 1. Constructing hybrid masculinity by male nurses Source: own elaboration.

Seemingly, male nurses are a uniform group, but in fact they are very diverse. When Wards (2015) analyses ways of defining men having sex with men, he infers that this practice does not significantly affect identity consequences. By analogy, the difference in nursing is the type of practice. Care may thus affirm masculinity, because it is essential which men from dominant groups participate in care and how they define it. In this context, care is essentially specialist, technical, requiring qualifications, far from nurturing activities of the lowest status. So, care is 'male', and better than 'feminine'. In this way, white straight men may work as nurses free from identity consequences, because the fact that they are engaged in care - if we take into account care in the above sense - does not affect the way masculinity is defined.

By definition, the profession of a male nurse is so close to practices of subordinated masculinities and femininity that distancing from hegemonic masculinity is immediately noticeable and needs no further explanations. In fear of too obvious distancing from dominant masculinity forms, a campaign was launched 'Are you men enough to be a nurse', whose aim was to encourage men to nursing and show that in no way it was getting close to subordinated masculinity. This campaign revealed how hybrid 
masculinity could be developed in nursing, because it showed men working as nurses in the context of hegemonic masculinity attributes, thus borrowing symbols from dominant forms of masculinity. The attributes let them be defined as surfers, motorcyclists, climbers or musicians. In the photographs even the body posture emphasized confidence and domination, being elements of dominant masculinity in line with cultural hegemony codes. Additionally, the images were subtitled 'Are you men enough to be a nurse', implying that nursing requires enough confidence to be a man. This technique, called soft essentialism (Messner 2011; Bridges \& Kimmel 2011), is based on an assumption that we are all equal but different, what in fact enhances inequalities. So, nursing is for men, but only for 'real men', i.e. men enjoying the privileges of men, and aspiring to dominant masculinity, who are able-bodied, strong, of 'masculine' interests, i.e. sport. This campaign brings a man closer to hegemonic masculinity and stems from the desire to neutralise distance and demonstrate attributes of dominant masculinity by those who undertake care, which by definition is associated with subordinated masculinities and femininities.

To conclude, privileged men define their hybrid masculinity by re-defining care. They work in nursing and they seem to accomplish - by the very fact of being engaged in care - caring masculinity, supporting at the same time pro-equality activities. To quote Messner (1993: 724) 'the change is more style than substance'.

\section{SUMMARY}

Hybrid masculinity creates a distance between a man and hegemonic masculinity, whereas in fact, it only replicates relationships between power and inequality (Bridges $\&$ Pascoe 2014). Being a male nurse seems to reduce the distance between hegemonic masculinity and care. However, re-defining care and using the fact that they are men in a feminised profession enhances dominant masculinity. As a borrowed element, care is defined through the prism of competence and know-how, and lets men distance and cut away from femininity and subordinated masculinities. This distancing concerns different ways of defining masculinity in the context of care because it also distances underprivileged men who cannot benefit from the patriarchal dividend. Therefore, the image of an educated person of high specialist competence and experience strengthens boundaries between other masculinities, for example working-class masculinities. On the other hand, by re-defining the notion of care, dominant masculinity can incorporate care as its attribute. In fact, a man performing a caring job, with care at its core, does not necessarily accomplish caring masculinity, which is pro-equality and rejects dominance by its very definition.

Being a nurse, i.e. undertaking care, does not always define the main axis of one's identity. Detailed studies on male nurses' motivation and career reveal a number of differences (Kluczyńska 2017b). As analyses show, caring masculinity in the context of care can be accomplished in various ways, and what matters is how care is defined. A question arises whether doing a caring job equals accomplishing caring masculinity and rejecting dominance (Kluczyńska 2017a). If caring masculinities is defined through a rejection of dominance and an integration of values from the realm of care 
(Elliott 2015), not all men working in care fit assumptions of caring masculinities. The fact that a man undertakes care is not synonymous with rejecting dominance. Re-defining care and incorporating it into dominant masculinity practices means that it is hard to perceive these men as accomplishing caring masculinity. For these reasons, in my opinion, hybrid masculinity is the most appropriate term to describe the analysed subgroup of nurses and the specificity and relationships between dominant masculinity and caring masculinities.

FUNDING: This research received no external funding.

CONFLICT OF INTEREST: The author declares no conflict of interest.

\section{REFERENCES}

Anderson, Eric. 2009. Inclusive masculinity: the changing nature of masculinities. New York: Routledge.

Baier, Annette. 1985. Postures of the mind: Essays on mind and morale. Minneapolis: University of Minnesota Press.

Barber, Kristen. 2008. "The Well-Coiffed Man: Class, Race and Heterosexual Masculinity in the Hair Salon.” Gender and Society" 22: 455-476. DOI: $10.1177 / 0891243208321168$

Berggren, Kalle. 2014. "Sticky Msculinity: Post-strukturalism, Phenomenology and Subjectivity in Critival Studies on Men.” Men and Masculinity 17: 231-252. DOI: $10.1177 / 1097184 X 14539510$

Bradley, Harriet. 1993. "Across the great divide: the entry of men into women's jobs.” Pp. 10-27 in Doing women's work: Men in non-traditional occupations, edited by Ch. L. Williams. London: Sage.

Bridges, Tristan. 2010. “Men just weren’t made to do this.” Gender Society 24: 5-30. DOI: $10.11 .77 / 0891243209356924$

Bridges, Tristan S. \& Michael Kimmel. 2011. "Engaging men in United States: Soft Essentialism and the obstacles to coherent initiatives in education and family policy.” Pp. 159-176 in Men and Masculinities Around the World: Transforming Men's Practices, edited by E. Ruspini, J. Hearn, B. Pease, \& K. Pringle. New York: Palgrave MacMillan.

Bridges, Tristan \& C. J. Pascoe. 2018. “On Elasticity of Gender Hegemony. Why hybrid Masculinities Fail to Undermine Gender and Sexual Inequality.” Pp. 254-274 in Gender Reckonings: New Social Theory and Research, edited by J. W. Messerschmidt, P.Y. Martin, M.A. Messner, R.W. Connell. New York: NYU Press.

Bridges, Tristan \& C. J. Pascoe. 2014. "Hybrid masculinities: New directions in the sociology of men and masculinities.” Sociology Compass 8(3): 246-258. DOI: $10.1111 /$ soc 4.12134

Centrum Badania Opinii Społecznej CBOS. 2019. Które zawody poważamy. Komunikat z badań. [Which professions we respect. Research report] Warszawa. (https://www. cbos.pl/SPISKOM.POL/2019/K_157_19.PDF). 
Charmaz, Kathy. 2006. Constructing grounded theory a practical guide through qualitative analysis. London, Thousand Oaks, New Delhi: Sage Publications.

Charmaz, Kathy. 2011 “Grounded theory methods in social justice research.” Pp. 507536 in The sage handbook of qualitative research 3rd edition, edited by N. K. Denzin \& Y. S. Lincoln. Los Angeles, London, New Delhi Singapore, Washington: Sage Publications.

Connell, R. W. 1987. Gender and Power: Society, the Persons and Sexual Politics. Sydney: Allen and Unwin.

Connell, R. W. 1995. Masculinities. Sydney: Allen \& Unwin.

Demetriou, Demetrakis Z. 2001. “Connell's Concept of Hegemonic Masculinity: A Critique." Theory and Society 30: 337-361. DOI: 10.1023/A:1017596718715

Domagała, Przemysław et al. 2013. „Percepcja mężczyzn wykonujących zawód pielęgniarza w społeczeństwie.” [Perception of male nurses in socjety] Problemy Pielęgniarstwa 21: 462-470.

Donovan, Brian. 1998. "Political consequences of private authority: Promise Keepers and the transformation of hegemonic masculinity." Theory and Society 27: 817843. DOI: $10.1023 / \mathrm{A}: 1006909132442$

Dziubak, Małgorzata \& Marek Motyka. 2013. "Motywy wyboru zawodu pielęgniarki i ich uwarunkowania - badania studentów kierunku pielęgniarskiego Collegium Medium Uniwersytetu Jagiellońskiego." ["Motivation behind the choice of nursing as a profession and its determinants-research among students of nursing at the Medical College of the Jagiellonian University”] Problemy Pielęgniarstwa 21: 281-289.

Elliott, Karla. 2015. “Caring masculinities: Theorizing an emerging concept.” Men and Masculinities 12: 1-20. DOI: 10.1177/1097184X15576203

Elliott, Karla. 2020. “Bringing in margin and centre: 'Open' and 'closed' as concepts for considering men and masculinities." Gender, Place \& Culture. DOI: 10.1080/0966369X.2020.1715348

Engster, Daniel. 2009. „Rozważania na temat teorii opieki: praktyka i obowiązek opieki.” Pp. 25-60 in Gender i ekonomika opieki, edited by E. Charkiewicz, A. Zachorowska-Mazurkiewicz. Warszawa: Biblioteka Think Tanku Feministycznego.

Fineman, Martha. 2004. The autonomy myth: A theory of dependency. New York: The New Press.

Fisher, Berenice \& Joan Tronto. 1990. “Towards a feminist theory of caring.” Pp. 35-62 in Circles of care: work and identity in women's lives, edited by E. Abel, M. Nelson. Albany State: University of New York Press.

Flood, Michael. 2015. "Men and gender equality.” Pp. 1-33 in Engaging men in building gender equality, edited by M. Flood, R. Howson. Newcastle upon Tyne: Cambridge Scholars Publishing.

Gilligan, Carol. 1982. In a different voice. Cambridge MA: Harvard University Press.

Hanlon, Niall. 2012. Masculinities, care and equality. Identity and nurture in men's live. London: Palgrave Macmillan.

Kapała, Wojciech \& Paweł Rucki. 2008. „Mężczyźni w polskim pielęgniarstwie. Jak widzą i oceniają swój zawód polscy pielęgniarze.” [„Polish male nurses. How do 
they perceive and assess their profession"] Pielegniarstwo Polskie 27: 7-13.

Kimmel, Michael. 1995. The Politics of Manhood: profeminist men respond to the mythopoetic men's movement (and the mythopoetic leaders answer). Philadelphia: Temple University Press.

Kimmell, Michael. 2013. Angry White Men: American Masculinity at the End of an Era. New York: Nation Books.

Kittay, Feder E. 1999. Love's labour: Essays on women, equality, and dependency. New York: Routledge.

Kluczyńska, Urszula. 2017a. Mężczyźni w pielęgniarstwie. W stronę męskości opiekuńczej. [Men in nursing. Caring masculinities] Poznań: Wyd. UMP.

Kluczyńska, Urszula. 2017b. "Motives for choosing and resigning from nursing by men in Poland and the definition of masculinity: a qualitative study." Journal of Advanced Nursing 73: 1366-1376. DOI: 10.1111/jan.13240

Kubisa, Julia. 2012. Bunt białych czepków. Analiza działalności związkowej pielęgniarek $i$ położnych. [The rebellion of the white bonnets. Analysis of the trade union activity of nurses and midewives] Warszawa: Scholar.

Mackintosh, Carolyn. 1997. "A historical study of men in nursing." Journal of Advanced Nursing 26: 232-236.

Masters, N. Tatiana. 2010. "'My Strength is Not for Hurting’: Men’s Anti-Rape Websites and their Construction of Masculinity and Male Sexuality.“ Sexualities 13: 33-46. DOI: 10.11.77/1363460709346115

Matthaei, Julie. 2001. “Healing ourselves, healing our economy: paid work, unpaid work and the next stage of feminist economic transformation." Journal of Radical Economic 33: 461-494. DOI: 10.1177/048661340103300406

Messner, Michael. 2007. “The Masculine of the Governator." Gender and Society 21: 461-480. DOI: 10.1177/0891243207303166

Messner, Michael. 2011. "Gender ideologies, youth sport, and the production of soft essentialism.” Sociology of Sport Journal 28: 151-170. DOI: 10.1123/ssj.28.2.151

Naczelna Izba Pielęgniarek i Położnych. 2018. Liczba pielęgniarek i położnych zarejestrowanych $i$ zatrudnionych [Numerer of registered and employed nurses and midwives] Warszawa (https://nipip.pl/liczba-pielegniarek-poloznych-zarejestrowanych-zatrudnionych).

O’Lynn, Chad E. 2007. “History of men in nursing. A review.” Pp. 5-23 in Men in nursing: history, challenges, and opportunities, edited by Ch. E. O’Lynn, R. E. Tranbarger. New York: Springer.

Philips, Judith. 2009. Troska. Warszawa: Wydawnictwo Sic!.

Sarvan, David. 1998. Talking Like A Men: White Masculinity, Maschimo, and Contemporary American Culture. Princeton, NJ: Princeton University Press.

Scambor Elli, Nadja Bergman, Katarzyna Wojnicka, Sophia Belghiti-Mahut, Jeff Hearn, Øysten Gullvåg Holter, Marc Gärtner, Majda Hrženjak, Christian Scambor, \& Alan White. 2014. "Men and gender equality: European insights.” Men and Masculinities 17: 553-554. DOI: 10.1177/1097184X14558239

Scambor, Elli, Katarzyna Wojnicka, \& Nadja Bergmann, eds. 2012. The Role of Men in Gender Equality - European strategies \& insights. Wien, Berlin, Graz. (http:// 
ec.europa.eu/justice/gender-equality/files/gender_pay_gap/130424_final_report_role_of_men_en.pdf).

Ungerson, Clare. 1987. Policy is personal: sex, gender and informal care. London: Tavistock.

Waling, Andrea. 2018. "Rethinking Masculinity Studies: Feminism, Masculinity, and Poststructural Accounts of Agency and Emotional Reflexivity." Journal of Men's Studies 27: 89-107. DOI: 10.1177/1060826518782980

Ward, Jane. 2015. Not gay. Sex between straight white men. New York: NYU Press.

\section{BIOGRAPHICAL NOTE}

Urszula Kluczyńska, a graduate of both sociology and pedagogy, is an associate professor at Collegium da Vinci in Poznań, Poland. Her research interests are focused on critical studies of men and masculinities, with particular emphasis on men's health, ageing, sexuality, sport, caring masculinities and medicalization of masculinity. She is an author of the following books: Mężczyźni w pielegniarstwie.W stronę męskości opiekuńczej [Men in nursing. Caring masculinities] (UMP Poznań 2017) and Metamorfozy tożsamości wspótczesnych młodych mężczyzn [Metamorphoses of men's identities in contemporary culture] (Adam Marszałek 2009), and co-author of Poza schematem. Społeczny konstrukt płci i seksualości [Beyond the scheme. Social construction of gender and sexuality] (with Wiktor Dynarski and Anna M. Kłonkowska) (Wydawnictwo Uniwersytetu Gdańskiego 2016). She is also a coeditor of three Special Issues, such as "Men and masculinities in the European dimension" (Studia Humanistyczne AGH), "Wymiary męskości" (Interalia), "Gender trouble-from producing and reproducing masculinities to ways of crossing gender" (Miscellanea Anthropologica et Sociologica), and an author of numerous articles on men and masculinities published in Polish books and journals. She is a member of the Polish Sociological Association and the Polish Gender Association.

OPEN ACCESS: This article is distributed under the terms of the Creative Commons Attribution Non-commercial License (CC BY-NC 4.0) which permits any non-commercial use, and reproduction in any medium, provided the original author(s) and source are credited. 